\title{
The potential for using acoustic tracking to monitor the movement of the West Coast rock lobster Jasus lalandii
}

\section{LJ Atkinson , S Mayfield \& AC Cockcroft}

To cite this article: LJ Atkinson, S Mayfield \& AC Cockcroft (2005) The potential for using acoustic tracking to monitor the movement of the West Coast rock lobster Jasus lalandii , African Journal of Marine Science, 27:2, 401-408, DOI: 10.2989/18142320509504099

To link to this article: http://dx.doi.org/10.2989/18142320509504099

曲制 Published online: 08 Jan 2010.

Submit your article to this journal $₫$

Џ Article views: 41

Q View related articles $\square$

Citing articles: 8 View citing articles 5 


\title{
The potential for using acoustic tracking to monitor the movement of the West Coast rock lobster Jasus lalandii
}

\author{
LJ Atkinson ${ }^{1 *}$, S Mayfield ${ }^{2}$ and AC Cockcroft ${ }^{3}$ \\ ${ }_{1}^{1}$ Marine Biological Research Institute, Department of Zoology, University of Cape Town, Private Bag, Rondebosch 7701, \\ South Africa \\ 2 South Australian Aquatic Sciences Centre, PO Box 120, Henley Beach, 5022 SA, Australia \\ ${ }^{3}$ Marine and Coastal Management, Department of Environmental Affairs and Tourism, Private Bag X2, Rogge Bay 8012, \\ South Africa \\ * Corresponding author, e-mail: latkinso@botzoo.uct.ac.za
}

\begin{abstract}
Although acoustic tracking has been used to study the movement of several species of clawed and spiny lobsters, only recent technological advances have provided sufficiently small transmitters to examine the utility of using acoustic tracking as a means to analyse the movement of relatively small spiny lobsters, such as Jasus lalandii. The effect of the transmitter on the mobility of $J$. lalandii was tested in aquarium experiments and was shown to have no influence on movement in three separate experiments. Thereafter, adult male rock lobsters (86-98mm carapace length) were tracked in field trials for up to $\mathbf{3 2}$ days at Betty's Bay $(n=4)$ and Hermanus $(n=5)$ off the Western Cape,
\end{abstract}

South Africa. Tracking J. Ialandii in the field using acoustic tags was successful, even in areas with dense kelp beds and rocky outcrops. The signal from the transmitters was readily detectable from the surface and subsequent use of underwater tracking equipment enabled visual confirmation of the position of the rock lobsters. Lobsters moved significantly longer distances $\left(>45 \mathrm{~m} \mathrm{day}^{-1}\right)$ in the first two days following tagging than during any subsequent time period $\left(<10 \mathrm{~m} \mathrm{day}^{-1}\right)$. This suggests that transmitter attachment and/or handling altered the movement pattern for the first 72 hours after tagging. During the period of observation, J. Ialandii displayed classical nomadic behaviour.

Keywords: acoustic tracking, acoustic transmitters, daily movements, rock lobster

Introduction

Where they occur in sufficient abundances, lobsters support valuable fisheries worldwide (Booth and Phillips 1994). Generally, their population dynamics and fisheries biology are well known. The West Coast rock lobster Jasus lalandii has commercially exploitable densities between Lüderitz in Namibia and just east of Cape Point along the South African west coast (Cockcroft and MacKenzie 1997). Much knowledge has been accumulated about this species (e.g. Heydorn 1969, Newman and Pollock 1971, Griffiths and Seiderer 1980, Barkai et al. 1996, Melville-Smith et al. 1995, Goosen and Cockcroft 1995, Cockcroft and Goosen 1995, Mayfield et al. 2000a, 2000b, Mayfield et al. 2001, Hazell et al. 2001). Although spatial assessment of tag-recapture data has shown that large-scale movements of adults are limited (Atkinson and Branch 2003), deciphering and classifying the mediumscale movement of $\mathrm{J}$. lalandii has been prevented by the lack of suitable methods to accurately record the position of individuals over extended periods of time. Information on the scale of natural movement patterns of this species would assist with management of the stock and evaluation of the efficacy of marine reserves in sustaining the resource.

Technological developments in the last decade have permitted more intensive and extensive exploration of movement patterns in marine mammals. These advances (including reductions in transmitter size, increased accuracy of tracking and reduction in cost) have enabled monitoring of the movements of several marine decapod crustaceans using acoustic technology (Wolcott and Hines 1990, Collins and Jensen 1992, Newland and Chapman 1993, van der Meeren 1997, Cote et al. 1998, Kelly 1999). Numerous studies have successfully used acoustics to track the movements of both clawed lobsters (van der Meeren 1997, Smith et al. 1998, 2000) and spiny lobsters (Chapman et al. 1975, Herrnkind 1980, Ramm 1980, Jernakoff et al. 1987, O'Dor and Webber 1991). The most spatially and temporally expansive assessment of rock lobster movement was undertaken by Kelly (1999) in which the movement patterns of 16 female and 16 male Southern rock lobster Jasus edwardsii were monitored for periods exceeding 350 days.

Compared to many clawed and spiny lobsters that have been tracked using acoustic technology, J. lalandii has a small body size. This has previously limited the investigation of J. lalandii's short-term movement using acoustics because the maximum weight added to the animal (transmitter and attachment) should not exceed $3-5 \%$ of the body weight (Caccamise and Hedin 1985) nor impede 
the normal mobility and behaviour of the tagged animal (Anderka and Angehrn 1992). Recent development of small transmitters provided the opportunity to test the utility of acoustically tracking $\mathrm{J}$. lalandii in its natural habitat of dense kelp beds and rocky reefs.

Acoustic telemetry has been identified as the most suitable means of tracking the movements of spiny lobsters (Cote et al. 1998). The present study evaluates the utility of this tool in investigating the medium-scale movement patterns of $J$. lalandii. Acoustic tracking only provides reliable information about a species' movement patterns when (1) the presence of the transmitter on the animal does not seriously impair its mobility or behaviour (Smith et al. 2000); (2) the long-term behaviour of tracked individuals is not affected by capture, attachment of the transmitter and subsequent release; and (3) the signal from the transmitter can be readily detected and used to track the species in its natural environment.

Following this, the paper has three components. First, following the recommendations of Smith et al. (2000), the mobility of tagged and non-tagged lobsters was compared, to assess the influence of transmitter attachment on the mobility of $J$. lalandii under laboratory conditions. Second, field-based tracking of $\mathrm{J}$. lalandii was undertaken at two sites to assess the practicality of using these transmitters to track $J$. lalandii in the field. Third, positional results on the movements of $J$. lalandii derived from the use of VEMCO V8-2LR transmitters are described.

\section{Material and Methods}

\section{Effect of the acoustic transmitter on mobility}

To assess the influence of transmitter attachment on mobility, 16 male rock lobsters (size range $85-97 \mathrm{~mm}$ carapace length [CL]) were captured using baited hoop-nets, and transported under cool conditions to the Marine and Coastal Management Aquarium, Cape Town. Structures simulating the shape and mass of the transmitters that were to be used in the field (VEMCO V8-2LR acoustic transmitters: length $51 \mathrm{~mm}$, diameter $9 \mathrm{~mm}$, weight $66 \mathrm{~g}$; Figure 1) were attached to the 'dry blotted' dorsal carapace surface of eight of the 16 rock lobsters using a fast-set glue gel (cyanoacrylate). The remaining eight rock lobsters did not have 'transmitters' attached to them and served as experimental control animals. Control and experimental animals were subjected to identical conditions. All rock lobsters were then released into a circular flow-through experimental tank, $3 \mathrm{~m}$ in diameter (water depth $0.6 \mathrm{~m}$ ). Twelve shelters, constructed from PVC pipes cut longitudinally in half, were provided in one half of the tank. Each shelter had an opening at either end and was large enough for a single rock lobster to occupy.

Following an acclimatisation period of seven days, three experiments were conducted, each three days apart. During each experiment, the rock lobsters were recorded on video from 18:00 to $19: 00$, the time of peak foraging activity (Paterson 1969, Zoutendyk 1988), using a video camera mounted above the tank. Sufficient illumination to observe the rock lobsters, yet ensuring minimal disturbance (Priede 1992), was provided from an infra-red light source. In the

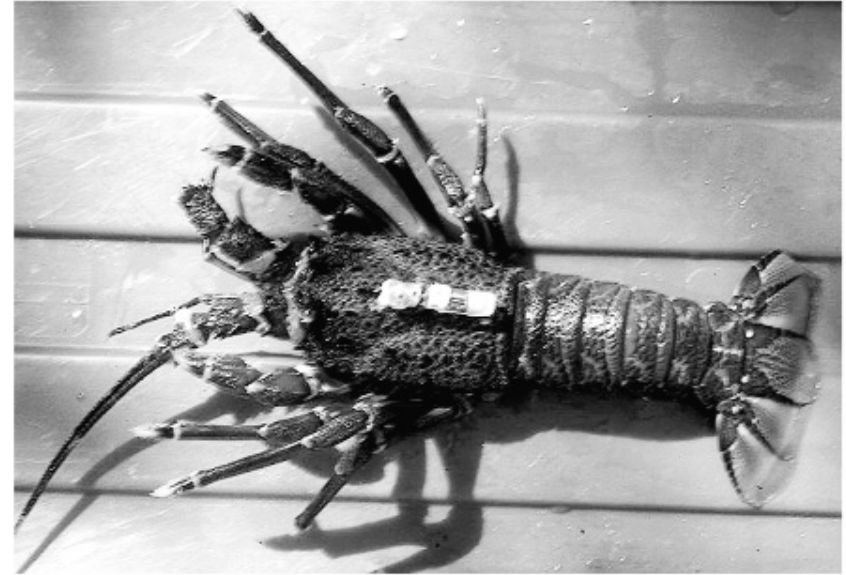

Figure 1: Photograph of an adult male rock lobster tagged with a VEMCO V8-2LR acoustic transmitter and colour-coded antennal tag (left hand antennae)

first experiment, no food was provided. In the subsequent two experiments, food (chunks of sardine Sardinops sagax in a weighted mesh bag) was initially provided on the floor of the tank at the opposite end to the shelters (Experiment 2 ), and subsequently on a raised fibreglass platform, $40 \mathrm{~cm}$ tall, $60 \mathrm{~cm}$ long and $50 \mathrm{~cm}$ wide (Experiment 3 ). The movement of each individual rock lobster was traced from the videotape onto a clear transparency. The tracings were then digitised into ArcView3 ${ }^{\circledR}$ (ESRI) GIS software. The total distance each rock lobster moved in 60 minutes was calculated, and used to compare the movements of tagged and non-tagged individuals for each of the three experiments. All data were log-transformed to achieve normality (Kolmogorov-Smirnov test) and homogeneity (Levene's test, $\alpha=0.05)$. The transformed data were analysed using a two-way ANOVA with transmitter (present or absent) and food (absent, benthic or raised) as fixed main effects (StatSoft, Inc. 1995 STATISTICA).

\section{Tracking in the field}

The potential for acoustically tracking $\mathrm{J}$. lalandii in the field was tested at Betty's Bay and Hermanus in the Western Cape Province, South Africa (Figure 2). The shallow subtidal areas $(<30 \mathrm{~m}$ water depth) at both these sites comprise large tracts of rocky reef covered by dense kelp Ecklonia maxima beds, interspersed with small sand patches (Field et al. 1980). Rock lobsters are highly abundant in both areas (Mayfield and Branch 2000).

At both Betty's Bay and Hermanus, the data collected comprised a series of Global Positioning System (GPS) positions for each rock lobster on each occasion it was located. The GPS positions were converted from degrees and minutes to radians to calculate the distance moved between each recorded position.

Betty's Bay

In February 2001, four male rock lobsters (size range: 86$98 \mathrm{~mm} \mathrm{CL}$ ) were hand-captured by experienced research 


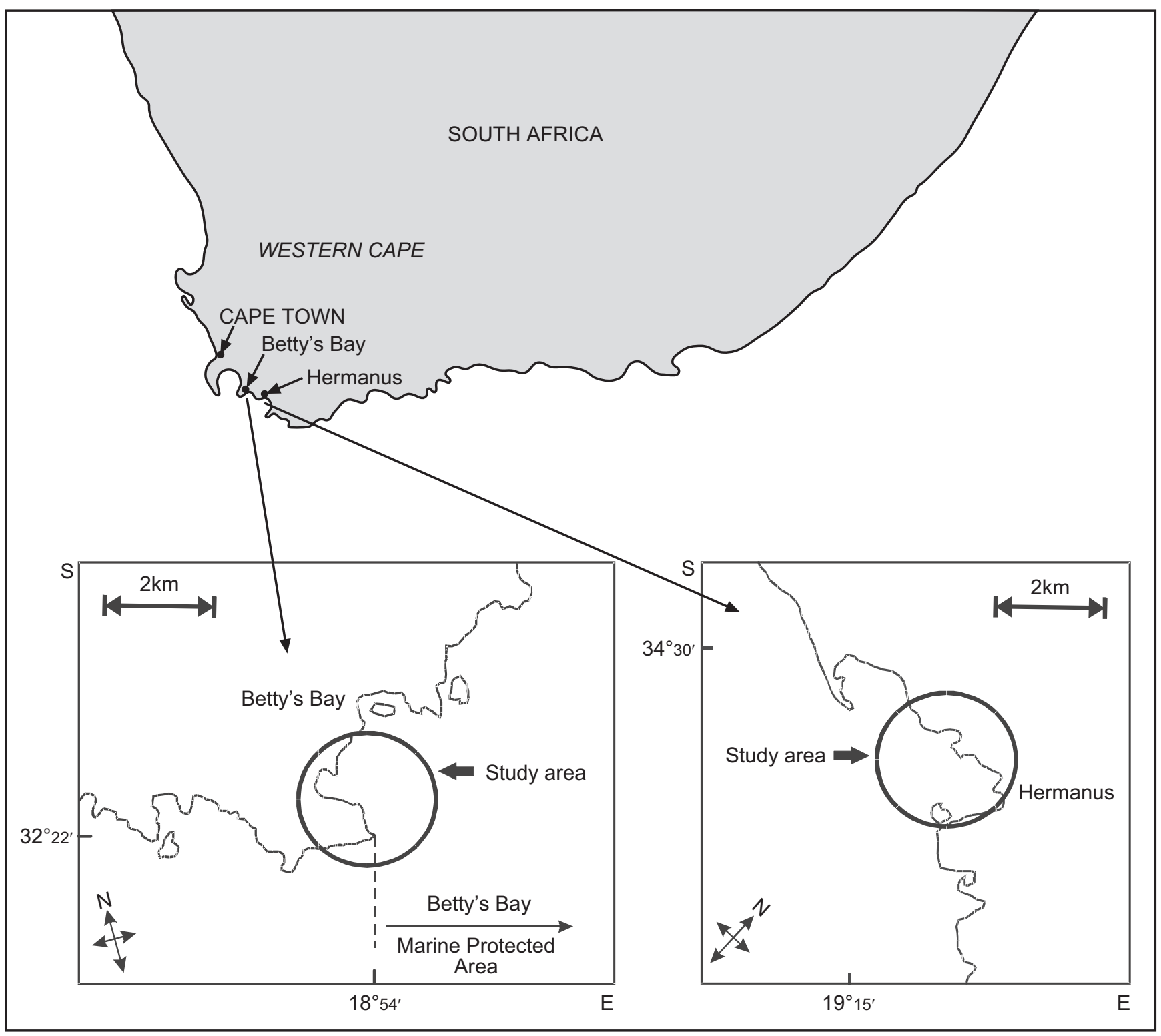

Figure 2: Locations of Betty's Bay and Hermanus, on the south coast of South Africa where the acoustic tracking studies of rock lobster were conducted

divers from $<10 \mathrm{~m}$ water depth. A VEMCO V8-2LR acoustic transmitter was attached to each rock lobster as described above. In addition, each rock lobster was tagged with a colour-coded antennal tag (after MacDiarmid et al. 1991). Tagged rock lobsters were returned (by hand) to the reef at the point of capture and the GPS co-ordinates of the points of release were recorded.

Approximately every four days for the 32 days following release, the areas surrounding the release locations were searched for the tagged rock lobsters, using a VR-60 ultrasonic receiver and $\mathrm{V}-10$ hydrophone (VEMCO Ltd) operated from a small boat. These receivers were used to identify the general location $(10 \mathrm{~m} \times 10 \mathrm{~m})$ of each rock lobster. A SCUBA diver then used a hand-held DPL-275A (Datasonics Inc.) pinger locator to search for each rock lobster underwater until it was visually located. This task was aided by the antennal tags that enabled identification of the transmitter-tagged rock lobsters with minimal disturbance, even when they were concealed in shelters or crevices. Once a rock lobster was located, the diver surfaced immediately, and the GPS co-ordinates of the diver on the surface were inferred to represent the position of the rock lobster. The precision of the GPS positions varied between $7 \mathrm{~m}$ and $15 \mathrm{~m}$. The transmitter was removed from each individual as it neared the end of the battery life, and the rock lobster was released.

\section{Hermanus}

In November 2001, baited hoop-nets were used to capture five male rock lobsters, (size range: $98-114 \mathrm{~mm} \mathrm{CL}$ ) at 
Hermanus. A VEMCO V8-2LR acoustic transmitter was attached on the dorsal surface of each rock lobster, which was then returned (by hand) to the reef and the GPS coordinates at the point of release recorded, as described above.

Twice daily (weather permitting) for 22 days following release, the areas surrounding the release locations were searched for the tagged rock lobsters from a small boat, using the same method as employed at Betty's Bay. The last known location of each rock lobster (identified by a surface marker buoy) served as the starting point for the subsequent search. Once the location of each rock lobster was reacquired, the GPS position was recorded and the marker buoy moved to the new position. Divers used the hand-held pinger locator to visually confirm the position of the rock lobsters on a regular basis, typically every three days.

\section{Results}

\section{Effect of the acoustic transmitter on the behaviour of Jasus lalandii}

The distance moved by rock lobsters carrying the artificial 'transmitters' did not differ significantly $(p>0.05)$ from that of rock lobsters without 'transmitters' under any of the three experimental conditions (Figure 3 ). Both tagged and nontagged rock lobsters moved significantly greater distances within the tank with food present compared to when food was absent $(p<0.001)$. However, the position of the food (either on the floor or on a raised platform) had no effect on the distance moved by either tagged or non-tagged rock lobsters (post-hoc Tukey HSD test, $p>0.05$ ).

\section{Tracking in the field}

The VEMCO V8-2LR acoustic tag was rapidly and easily attached to the captured rock lobsters in the field. Rock lobsters were removed from the water for a maximum period of five minutes.

The acoustic signal from the transmitters was readily detected from the surface, even in areas of rocky reefs and/or dense kelp beds. The hand-held pinger locator enabled confirmation of the presence of the tagged rock lobsters through underwater observation, and allowed for precise positions to be obtained. Detection of the signal from the transmitters was more difficult during periods following high wave action, when particulate matter was abundant in the water column. If a rock lobster was located at the back of a deep cave $(>2 m)$, the signal from the transmitter was only detectable if the hydrophone was positioned directly outside (at the surface) the entrance to the cave.

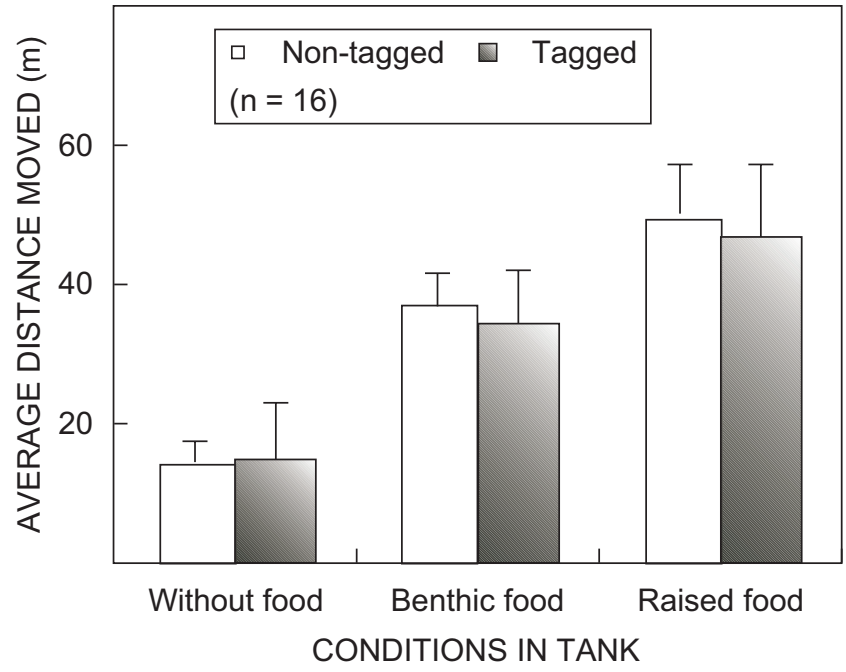

Figure 3: Distance moved per hour by tagged and non-tagged rock lobsters in the absence of food, or with food provided on the floor of the tank or on a raised platform. Error bars denote $+1 \mathrm{SE}$

At neither site were there clear or consistent directional movements by any of the rock lobsters (Figure 4). They typically remained in the same location for several days, before moving to a different location. Therefore, observed movements were rare but definitive rather than frequent and small. Individual rock lobsters moved a range of distances and directions, frequently turning back on their own paths. Net displacement distances (range: 5-363m) were similar at the two sites (Tables 1 and 2).

At Betty's Bay, rock lobsters were tracked between 14 and 32 days (Table 1). During that period, movement rates varied between $4 \mathrm{~m}$ and $36 \mathrm{~m}$ day $^{-1}$. The shortest total distance moved was $62 \mathrm{~m}$ over 15 days, the greatest was $1146 \mathrm{~m}$ over a period of 32 days. The average rate of movement was $15.5 \mathrm{~m}$ day $^{-1}$, most $(76 \%)$ movement being $<25$ m day $^{-1}$ (Figure 5). The greatest individual rate of movement between sequential positions was $212 \mathrm{~m}$ day $^{-1}$.

At Hermanus, rock lobsters were tracked for between 7 and 22 days (Table 2). Rates of movement were similar to those observed at Betty's Bay and ranged between $4 \mathrm{~m}$ and $31 \mathrm{~m} \mathrm{day}$ dat $^{-1}$. Total distances moved were considerably smaller at Hermanus, ranging from $18 \mathrm{~m}$ to $226 \mathrm{~m}$ over the tracking period. The largest distance moved by an individual in one day was $135 \mathrm{~m}$ (Figure 4). Significantly greater movements were observed in the first two days following tagging, than during any subsequent time period (KruskalWallis ANOVA by ranks, $p=0.0002$; Figure 6).

Table 1: Summary of data obtained from acoustically tracked J. lalandii at Betty's Bay

\begin{tabular}{cccccrr}
\hline $\begin{array}{c}\text { Size } \\
(\mathrm{CL} \mathrm{mm})\end{array}$ & $\begin{array}{c}\text { Length of tracking } \\
\text { period (days) }\end{array}$ & $\begin{array}{c}\text { Net displacement } \\
(\mathrm{m})\end{array}$ & $\begin{array}{c}\text { Total distance } \\
\text { moved }(\mathrm{m})\end{array}$ & $\begin{array}{c}\text { Rate of movement } \\
\left(\mathrm{m} \text { day }{ }^{-1}\right)\end{array}$ & $\begin{array}{c}\text { Depth } \\
\text { range }(\mathrm{m})\end{array}$ & $\begin{array}{c}\text { Number of } \\
\text { recorded positions }\end{array}$ \\
\hline 86 & 32 & 5 & 1146 & 35.8 & $5-15$ & 9 \\
90 & 14 & 31 & 62 & 4.1 & 5 & 5 \\
90 & 32 & 363 & 522 & 16.3 & $5-17$ & 7 \\
98 & 22 & 9 & 127 & 5.8 & 5 & 7 \\
\hline
\end{tabular}



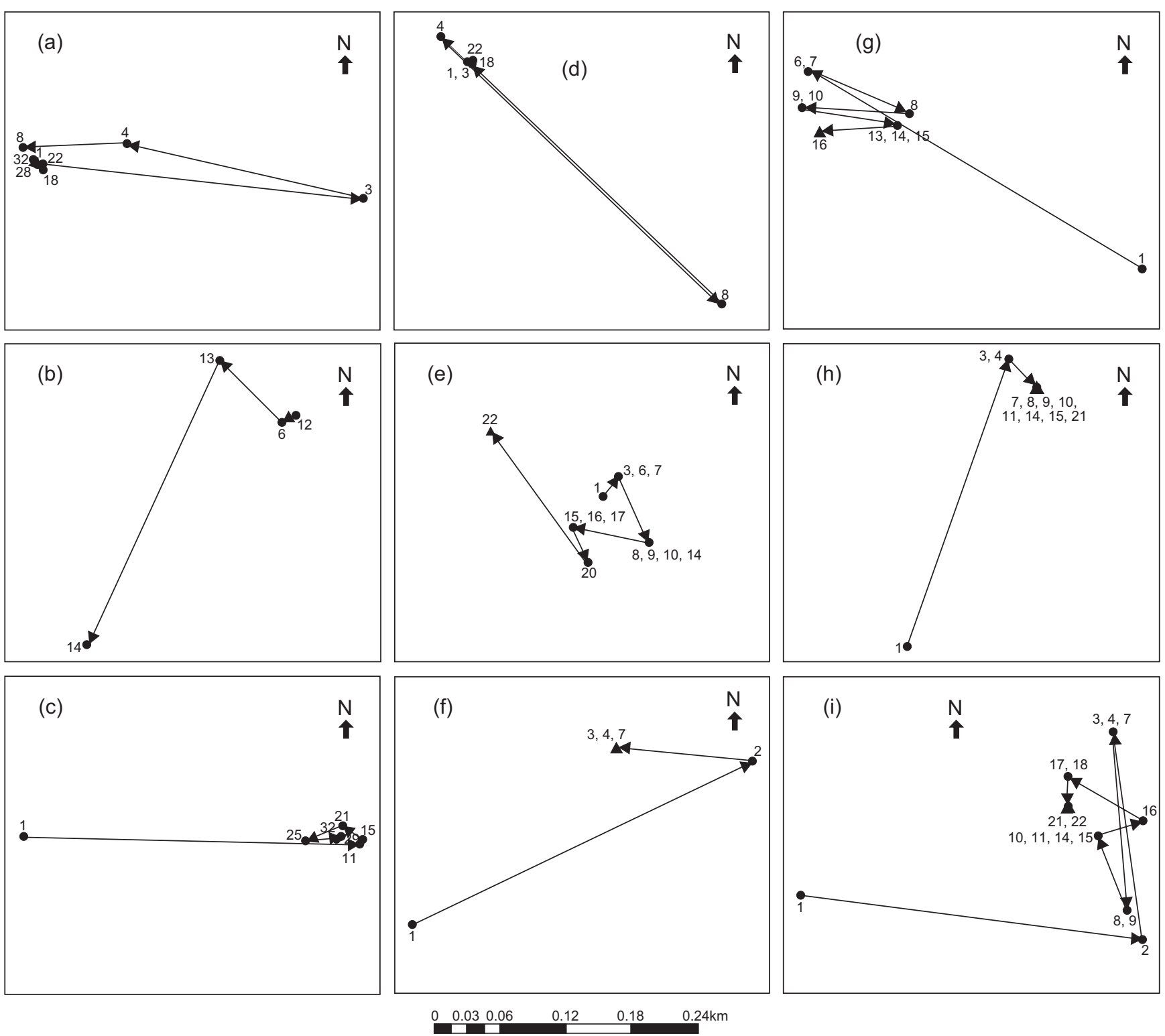

Figure 4: Locations of the tagged rock lobsters at (a-d) Betty's Bay and (e-i) Hermanus, on the first occasion on each day they were observed following release. Numbers indicate the time (days) since release. A triangle indicates each rock lobster's position when it was recaptured and the tag removed

Table 2: Summary of data obtained from acoustically tracked J. lalandii at Hermanus

\begin{tabular}{ccccccc}
\hline $\begin{array}{c}\text { Size } \\
(\mathrm{CL} \mathrm{mm})\end{array}$ & $\begin{array}{c}\text { Length of tracking } \\
\text { period (days) }\end{array}$ & $\begin{array}{c}\text { Net displacement } \\
(\mathrm{m})\end{array}$ & $\begin{array}{c}\text { Total distance } \\
\text { moved }(\mathrm{m})\end{array}$ & $\begin{array}{c}\text { Rate of movement } \\
\left(\mathrm{m} \text { day }{ }^{-1}\right)\end{array}$ & $\begin{array}{c}\text { Depth } \\
\text { range }(\mathrm{m})\end{array}$ & $\begin{array}{c}\text { Number of } \\
\text { recorded positions }\end{array}$ \\
\hline 91 & 7 & 34 & 60.8 & 30.4 & 5 & 5 \\
98 & 21 & 136 & 226.2 & 30.8 & $5-13$ & 19 \\
108 & 22 & 18 & 18.0 & 3.9 & $7-10$ & 17 \\
109 & 16 & 33 & 149.7 & 16.6 & $7-19$ & 11 \\
114.4 & 22 & 9 & 168.5 & 22.1 & $5-14$ & 17 \\
\hline
\end{tabular}




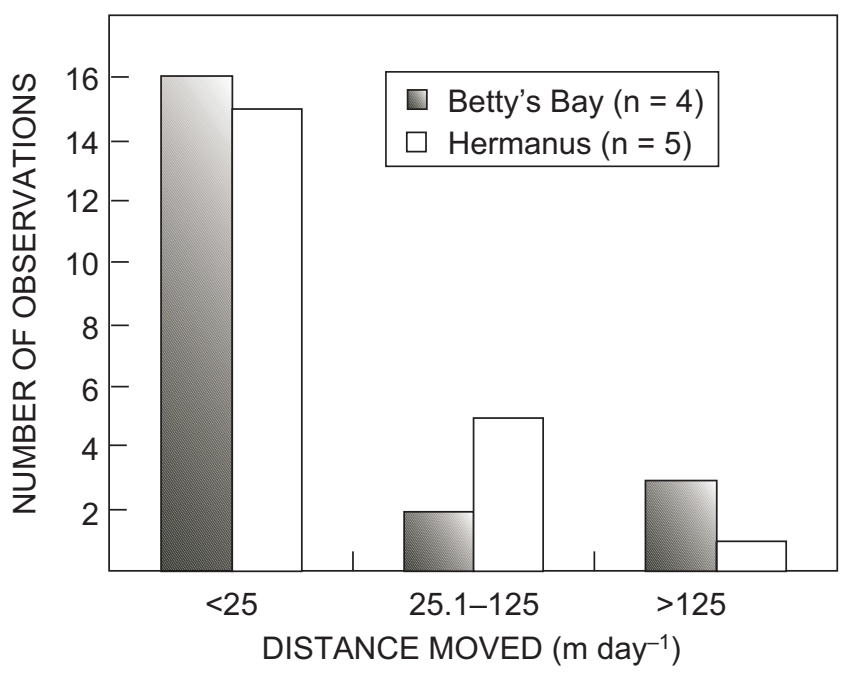

Figure 5: Distances moved by rock lobsters at Betty's Bay and Hermanus

\section{Discussion}

Acoustic tracking of aquatic animals such as decapod crustaceans can reveal valuable detailed information relating to their activities and movement over large spatial and temporal scales. The movement of rock lobsters has been studied using acoustic tracking in Canada, Norway, New Zealand and the United States (O'Dor et al. 1998, Kelly 1999). In particular, remote sensing has focussed on commercially important lobster species over the past 30 years (Chapman et al. 1975, Herrnkind 1980), including Jasus edwardsii (Kelly 1999), J. novaehollandiae (Ramm 1980), Panulirus cygnus (Jernakoff et al. 1987), Homarus americanus (Tremblay et al. 1999) and $H$. gammarus (van der Meeren 1997, Smith et al. 1998, 2000).

The present study demonstrates that the small lightweight VEMCO V8-2LR transmitters had little effect on the mobility of $J$. lalandii in the three aquarium experiments. In this controlled environment, average distances moved by tagged (individuals with a 'transmitter' attached) and nontagged individuals were similar, irrespective of whether food was present or absent.

The second requirement for acoustic tracking to be successful is the ability to detect the signal from the tagged rock lobsters in their natural environment. J. lalandii inhabits rocky reefs and dense kelp beds that potentially could affect the transmission, and hence detection, of the acoustic signal. The success with which individual rock lobsters were tracked over lengthy periods at both Betty's Bay and Hermanus was encouraging. The signal could be readily detected from a distance exceeding $30 \mathrm{~m}$ using surfacetracking equipment, and subsequent diver-operated underwater tracking equipment enabled visual confirmation. This study clearly demonstrates the effectiveness, accuracy and efficiency of acoustically tracking $\mathrm{J}$. lalandii in their natural habitat.

Two of the nine tagged rock lobsters were 'lost' during the tracking period, one each at Betty's Bay and Hermanus.

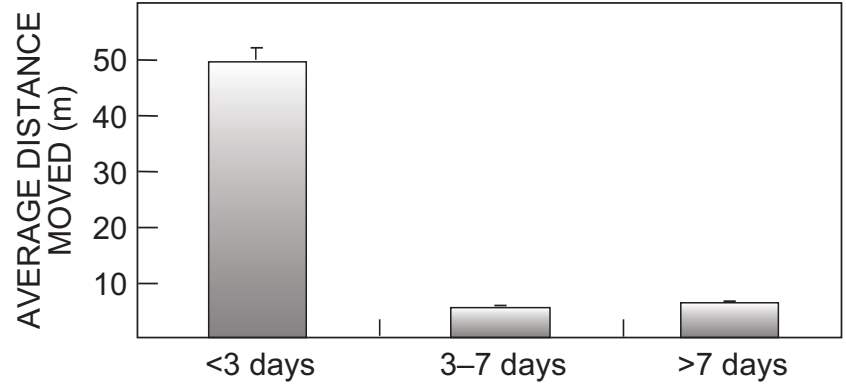

Figure 6: Average distance moved by rock lobsters at Hermanus for periods $<3$ days, 3-7 days and $>7$ days post tagging. Error bars denote $+1 \mathrm{SE}$

These individuals may have moved a substantial distance from their previous location, and thus outside the search area, or they may have been eaten. Alternatively, the acoustic tag may have failed. Such losses were not unexpected, and do not detract from the conclusions reached here.

Rock lobsters fitted with acoustic tags and released at Hermanus moved substantially greater distances during the first 72 hours post-release than during either of the other time periods examined (Figure 6). Unfortunately, comparable data were not obtained during the laboratory experiments (rock lobsters were acclimated to the experimental tank for seven days before experiments were initiated), nor collected at Betty's Bay. The data from Hermanus suggest that, despite extremely careful handling by skilled researchers, the capture, handling associated with transmitter attachment and subsequent release may have altered the short-term movement patterns of these rock lobsters during the days immediately following tagging.

Similar capture-and-handling induced movements were observed in J. edwardsii by MacDiarmid et al. (1991). They demonstrated that there was an increased likelihood of greater movement by this species during the first 24 hours following capture. Further, Jernakoff (1987) observed that some $P$. cygnus 'disappeared' within the first few nights after tagging. Therefore, movements of $J$. lalandii during the first few days post-tagging should be interpreted with caution in future assessment of their medium-scale movement patterns using the current method.

In summary, the present results demonstrate that the transmitters are sufficiently small so as to have no effect on the mobility of the J. lalandii. The signal from the transmitters tested was readily detectable when attached to several rock lobsters captured from, and subsequently released back into, their natural environment. Data from one site (Hermanus) suggest that the capture, tagging and release process may substantially affect the short-term post-tagging behaviour of this species, despite cautious handling of individual rock lobsters.

The present results suggest that $J$. lalandii exhibits nomadic behaviour, rather than occupying home ranges (Herrnkind 1980). Notably, the tagged individual rock lobsters remained in small areas for varying periods of time before abruptly moving to a new location. None of the individuals observed returned to any previously occupied 
position. These data, in combination with the daily movement patterns observed (up to $212 \mathrm{~m}$ day $^{-1}$ ), indicate that small marine protected areas (MPAs) are less likely to afford substantial benefits than larger ones. In the course of their normal movement patterns, individual rock lobsters may frequently traverse the boundaries of small MPAs, outside of which they would be exposed to fishing pressure. Given the current re-assessment of the MPA network along the South African coastline (Attwood et al. 1997, Mayfield et al. 2005), quantitative data on daily movements of rock lobsters would be timely. A hydro-acoustic buoy array system could facilitate collection of large amounts of information on the movement of numerous rock lobsters at multiple sites for extended periods of time.

Acknowledgements - Funds were provided by the National Research Foundation of South Africa and the Marine and Coastal Management (MCM) branch of the Department of Environmental Affairs and Tourism. We thank the staff from MCM, in particular Mr D van Zyl and Mr C Wilke and various colleagues from the University of Cape Town for assistance in the field. Prof. GM Branch is thanked for his continued support and guidance, following his initiation of the project and for constructively commenting on earlier drafts of this paper. Thanks are due to Annette Doonan for creating Figure 4. All experiments conducted during this study were in compliance with the applicable laws and regulations of South Africa and concurred with the ethical requirements of the University of Cape Town.

\section{References}

ANDERKA, F. W. and P. ANGEHRN 1992 - Transmitter attachment methods. In Wildlife Telemetry: Remote Monitoring and Tracking of Animals. Priede I. G. and S. M. Swift (Eds). Great Britain; Ellis Horwood: 135-146.

ATKINSON, L. J. and G. M. BRANCH 2003 - Longshore movements of adult male Jasus lalandii: evidence from longterm tag recaptures. Afr. J. mar. Sci. 25: 387-390.

ATTWOOD. C. G., MANN, B. Q., BEAUMONT, J. and J. M. HARRIS 1997 - Review of the state of marine protected areas in South Africa. S. Afr. J. mar. Sci. 18: 341-367.

BARKAI, A., DAVIS, C. L. and S. TUGWELL 1996 - Prey selection by the South African Cape rock lobster Jasus lalandii: ecological and physiological approaches. Bull. mar. Sci. 58: 1-8.

BOOTH, J. D. and B. F. PHILLIPS 1994 - Early life history of spiny lobster. Crustaceana 66: 271-294.

CACCAMISE, D. F. and R. S. HEDIN 1985 - An aerodynamic basis for selecting transmitter loads in birds. Wilson Bull. 97: 306-318.

CHAPMAN, C. J., JOHNSTONE, A. D. F. and A. L. RICE $1975-$ The behaviour and ecology of the Norway lobster, Nephrops norvegicus (L.). In Proceedings of the $9^{\text {th }}$ European Marine Biology Symposium. Barnes, H (Ed.). Aberdeen; University Press: $50-74$.

COCKCROFT, A. C. and P. C. GOOSEN 1995 - Shrinkage at moulting in the rock lobster Jasus lalandii and associated changes in reproductive parameters. S. Afr. J. mar. Sci. 16: 195-203.

COCKCROFT, A. C. and A. J. MacKENZIE 1997 - The recreational fishery for West Coast rock lobster Jasus lalandii in South Africa. S. Afr. J. mar. Sci. 18: 75-84.

COLLINS, K. J. and A. C. JENSEN 1992 - Acoustic tagging of lobsters on the Poole Bay artificial reef. In Wildlife Telemetry: Remote Monitoring and Tracking of Animals. Priede, I. G. and S. M. Swift (Eds). Great Britain; Ellis Horwood: 355-358.
COTE, D., SCRUTON, D. A., NIAZGODA, G. H., McKINLEY, R. S., ROWSELL, D. F., LINDSTROM, R. T., OLLERHEAD, L. M. N. and C. J. WHITT 1998 - A coded acoustic telemetry system for high precision monitoring of fish location and movement: application to the study of nearshore nursery habitat of juvenile Atlantic cod (Gadus morhua). Mar. Technol. Soc. J. 32: 54-62.

FIELD, J. G., GRIFFITHS, C. L., GRIFFITHS, R. J., JARMAN, N. [G.], ZOUTENDYK, P., VELIMIROV, B. and A. BOWES $1980-$ Variation in structure and biomass of kelp communities along the southwest Cape coast. Trans. R. Soc. Afr. 44(2): 145-203.

GOOSEN, P. C. and A. C. COCKCROFT 1995 - Mean annual growth increments for male West Coast rock lobster Jasus lalandii, 1969-1993. S. Afr. J. mar. Sci. 16: 377-386.

GRIFFITHS, C. L. and J. L. SEIDERER 1980 - Rock lobsters and mussels - limitations and preferences in a predator-prey interaction. J. expl mar. Biol. Ecol. 44(1): 95-109.

HAZELL, R. W. A., COCKCROFT, A. C., MAYFIELD, S. and M. NOFFKE 2001 - Factors influencing the growth rate of juvenile rock lobsters, Jasus lalandii. Mar. Freshwat. Res. 52: 13671373.

HERRNKIND, W. F. 1980 - Spiny lobsters: patterns of movement. In Biology and Management of Lobsters. Cobb J. S. and B. F. Phillips (Eds). New York; Academic Press: 349-407.

HEYDORN, A. E. F. 1969 - The rock lobster of the South African west coast Jasus lalandii ( $\mathrm{H}$. Milne Edwards). 2. Population studies, behaviour, reproduction, moulting, growth and migration. Investl Rep. Div. Sea Fish. S. Afr. 71: 52 pp

JERNAKOFF, P. 1987 - Foraging patterns of juvenile western rock lobsters Panulirus cygnus George. J. expl mar. Biol. Ecol. 113: $125-144$.

JERNAKOFF, P., PHILLIPS, B. F. and R. A. MALLER 1987 - A quantitative study of nocturnal foraging distances of the western rock lobster Panulirus cygnus George. J. expl mar. Biol. Ecol. 113: 9-21.

KELLY, S. 1999 - Marine reserves and the spiny lobster. Ph.D. thesis, University of Auckland: $145 \mathrm{pp}$.

MacDIARMID, A. B., HICKEY, B. and R. A. MALLER 1991 - Daily movement patterns of the spiny lobster Jasus edwarsii (Hutton) on a shallow reef in northern New Zealand. J. expl mar. Biol. Ecol. 147: 185-205.

MAYFIELD, S., ATKINSON, L. A., BRANCH, G. M. and A. C. COCKCROFT 2000a - Diet of the West Coast rock lobster, Jasus lalandii: influence of lobster size, sex, capture depth, latitude and moult stage. S. Afr. J. mar. Sci. 22: 57-69.

MAYFIELD, S. and G. M. BRANCH 2000 - Interrelations among rock lobsters, sea urchins, and juvenile abalone: implications for community management. Can. J. Fish. aquat. Sci. 57: 21752185.

MAYFIELD, S., BRANCH, G. M. and A. C. COCKCROFT 2000b Relationships among diet, growth rate and food availability for the South African rock lobster, Jasus lalandii. Crustaceana 73: 815-834.

MAYFIELD, S., BRANCH, G. M. and A. C. COCKCROFT $2005-$ Role and efficacy of marine protected areas for the South African rock lobster, Jasus lalandii. Mar. Freshwat. Res. 56: 1-16.

MAYFIELD, S., DEBEER, E. and G. M. BRANCH 2001 - Sea urchin consumption, prey species preference and predation on abalone by captive rock lobsters (Jasus lalandii). Mar. Freshwat. Res. 52: 773-780.

MELVILLE-SMITH, R., GOOSEN, P. C. and T. J. STEWART 1995 - The spiny lobster Jasus lalandii (H. Milne Edwards, 1837) off the South African coast: inter-annual variations in male growth and female fecundity. Crustaceana 68(2): 174-183.

NEWLAND, P. L. and C. J. CHAPMAN 1993 - Locomotory behaviour and swimming performance of the Norway lobster, Nephrops 
norvegicus, in the presence of an acoustic tag. Mar. Biol. 115: 33-37.

NEWMAN, G. G. and D. E. POLLOCK 1971 - Biology and migration of rock lobster Jasus lalandii and their effect on availability at Elands Bay, South Africa. Investl Rep. Div. Sea Fish. S. Afr. 94: $24 \mathrm{pp}$.

O'DOR, R. K., ANDRADE, Y., WEBBER, D. M., SAUER, W. H. H., ROBERTS, M. J., SMALE, M. J. and F. M. VOEGELI 1998 Applications and performance of Radio-Acoustic Positioning and Telemetry (RAPT) systems. Hydrobiologia 371: 1-8.

O'DOR, R. K. and D. M. WEBBER 1991 - Ultrasonic telemetry. Lobster Newsletter. 4: 1-2.

PATERSON, N. F. 1969 - The behaviour of captive Cape rock lobsters, Jasus lalandii (H. Milne-Edwards). Ann. S. Afr. Mus. 52(10): 225-264.

PRIEDE, I. G. 1992 - Wildlife telemetry: an introduction. In Wildlife Telemetry: Remote Monitoring and Tracking of Animals. Priede, I. G. and S. M. Swift (Eds). Great Britain; Ellis Horwood Ltd: 3-25.

RAMM, D. C. 1980 - Electromagnetic tracking of rock lobsters (Jasus novaehollandiae). Aust. J. mar. Freshwat. Res. 31: 263-269.

SMITH, I. P., COLLINS, K. J. and A. C. JENSEN 1998 - Movement and activity patterns of the European lobster, Homarus gammarus, revealed by electromagnetic telemetry. Mar. Biol. 132: 611-623.

SMITH, I. P., COLLINS, K. J. and A. C. JENSEN 2000 - Digital electromagnetic telemetry system for studying behaviour of decapod crustaceans. J. expl mar. Biol. Ecol. 247: 209-222.

TREMBLAY, M. J., DUGGAN, R., O'DOR, R., CURTIS, C., WEBBER, D. and Y. ANDRADE 1999 - Daily movements of lobsters from ultrasonic tracking. J. Shellfish Res. 18: 307.

VAN DER MEEREN, G. I. 1997 - Preliminary acoustic tracking of native and transplanted European lobsters (Homarus gammarus) in an open sea lagoon. Mar. Freshwat. Res. 48: 915-921.

WOLCOTT, T. G. and A. H. HINES 1990 - Ultrasonic telemetry of small-scale movements and microhabitat selection by molting blue crabs (Callinectes sapidus). Bull. mar. Sci. 46: 83-94.

ZOUTENDYK, P. 1988 - Feeding, defaecation and absorption efficiency in the Cape rock lobster Jasus lalandii. S. Afr. J. mar. Sci. 6: 59-65. 